\title{
PENGELOLAAN PENATAAN RUANG KANTOR TERHADAP KENYAMANAN BEKERJA PEGAWAI PADA SEKSI BIMBINGAN MASYARAKAT ISLAM KANTOR KEMENTRIAN AGAMA KOTA MOJOKERTO
}

\author{
Bambang Sunaryadi, Daffa Eksa Rizky, Afi Mustaghfiroh, \\ Mukhlishah, \\ UIN Sunan Ampel, Surabaya - Indonesia | bambangsunaryadi452@gmail.com
}

\begin{abstract}
Abstrak: Penelitian ini bertujuan untuk mengetahui pengelolaan penataan ruang kantor terhadap kenyamanan bekerja pegawai Seksi Bimas Islam Kantor Kementrian Agama Kota Mojokerto. Penelitian ini menggunakan metode deskriptif kualitatif. Subjek dalam penelitian ini yakni Plt. Kasi Bimbingan Masyarakat Islam dan Pegawai Seksi Bimbingan Masyarakat Islam. Setelah dilakukan penelitian, dapat disimpulkan bahwa pengelolaaan penataan ruang kantor seksi bimas islam belum sepenuhnya efektif dan efisien untuk melakukan berbagai macam pekerjaan. Terdapat berbagi kendala yang harus diatasi yaitu dengan penataan kembali ruang kantor bimas. Salah satu hal yang dapat membuat kenyamanan dalam bekerja adalah pengelolaan penataan ruang kantor yang baik. Apabila pengelolaan penataan ruang kantor sudah dilakukan dengan baik dan mememenuhi asas-asas penataan ruang kantor maka akan membuat pegawai menjadi nyaman dalam bekerja. Apabila pegawai telah merasa nyaman dalam melakukan pekerjaannya, maka akan mempercepat dalam penyelesaian pekerjaan, sehingga meningkatkan kinerja dari pegawai tersebut.
\end{abstract}

Keywords: Tata Ruang Kantor, Kenyamanan Bekerja Pegawai

\section{Pemdahuluan}

Tatanan ruang kantor merupakan aspek penting yang perlu dikelola untuk menunjang kinerja pegawai. Tatanan sebuah kantor akan menggambarkan bagaimana pegawai yang berada di dalam kantor tersebut dalam kesehariannya. Tata ruang kantor yang tidak baik akan membuat pegawai yang bekerja di dalamnya menjadi tidak nyaman dalam melakukan pekerjaannya. Ketidaknyamanan 
tersebut akan menghambat kinerja dari pegawai tersebut dalam melaksanakan pekerjaannya, dan akan berpengaruh juga kepada kinerja organisasi atau lembaga tersebut. Maka dari itu, pengelolaan tatanan ruang kantor yang baik akan memudahkan pegawai dalam bekerja, dapat menciptakan kenyamanan saat bekerja dan dapat bekerja secara optimal sehingga menunjukkan hasil yang baik. 1

Pengelolaan penataan ruang kantor yang tepat, penting untuk diterapkan di instansi pemerintah, termasuk di Kantor Kementrian Agama. Kementrian Agama adalah kantor yang membidangi urusan agama di provinsi/kabupaten/kota di Indonesia. Salah satunya adalah Kantor Kementrian Agama Kota Mojokerto. Kantor Kementrian Agama Kota Mojokerto di dalamnya memiliki beberapa satuan kerja yang memiliki fungsinya masing-masing dalam membantu kelancaran aktivitas di Kantor Kementrian Agama Kota Mojokerto. Beberapa satuan kerja di Kantor Kementrian Agama Kota Mojokerto adalah sebagai berikut; Urusan Umum, Analis Kepegawaian, Urusan Keuangan, Seksi Pakis (Pendidikan Agama dan Keagamaan Islam), Seksi Pendma (Pendidikan Madrasah), Seksi Penyelenggara Syariah, Seksi Penyelenggara Haji dan Umroh. Seksi Bimas (Bimbingan Masyarakat Islam), Seksi pokjawas.

Setiap satuan kerja di Kantor Kementrian Agama Kota Mojokerto memiliki ruangan kerjanya masing-masing, salah satunya yakni Seksi Bimbingan Masyarakat Islam. Terdapat berbagai masalah dalam penataan ruang kantor dan perabotan kantor., penataan meja dan kursi staf, terdapat perabotan kantor yang tidak terpakai di dalam ruangan, dan penataan arsip yang belum tertata dengan rapi meskipun sudah terdapat lemari arsip diruangan tersebut.

Berdasarkan latar belakang tersebut, dapat disusun rumusan masalah yakni (1) Bagaiaman Pengelolaan Penataan Ruang Kantor Seksi Bimbingan Masyarakat Islam? (2) Bagaimana Kenyamanan Bekerja Pegawai Seksi Bimas Islam? (3) Bagaimana Pengelolaan

${ }^{1}$ Firda Noor Oktavianti, “Analisis Tat Ruang Dalam Kenyamanan Kerja Dan Optimalisai Kinerja Bagian Humas Dan Protocol Secretariat DPRD Kota Surakarta”, Jurnal Informasi Dan Komunikasi, Volume 2 Nomor 3, 2018, 73 
Penataan Ruang Kantor Terhadap Kenyamanan Bekerja Pegawai Seksi Bimas Islam Kantor Kementrian Agama Kota Mojokerto?

Berdasarkan rumusan masalah tersebut, maka tujuan dari penelitian ini adalah untuk mengetahui Pengelolaan Penataan Ruang Kantor Seksi Bimbingan Masyarakat Islam, Untuk Mengetahui Kenyamanan Bekerja Pegawai Seksi Bimas Islam, Untuk Mengetahui Pengelolaan Penataan Ruang Kantor Terhadap Kenyamanan Bekerja Pegawai Seksi Bimas Islam Kantor Kementrian Agama Kota Mojokerto.

Kantor merupakan sebuah tempat yang biasanya digunakan untuk mengerjakan pekerjaan tata usaha (Moekijat, 1997:3). Sebagai salah satu penunjang aktivitas kantor dapat menggunakan sarana dan prasarana kantor, perabotan kantor, fasilitas kantor, serta alatalat kantor.2 Tata ruang kantor merupakan pengaturan ruangan kantor dan penyusunan alat-alat serta perabotan kantor pada ruangan kantor yang tersedia, untuk memberikan sarana yang baik bagi para pekerja. Setiap pegawai kantor memerlukan tempat yang nyaman untuk bekerja. Salah satu sarana perkantoran yang patut untuk dikelola adalah ruangan untuk bekerja. Tatanan tempat bekerja menentukan lancar atau tidaknya kegiatan perkantoran. Selain itu tatanan tempat bekerja juga mempengaruhi kenyamanan pegawai dalam bekerja. Tatanan tempat kerja yang baik akan mendukung pekerjaan kantor selesai dengan semestinya. 3

Terdapat bebrapa tujuan yang perlu dicapai dalam penyusunan tata ruang kantor. Tujuan tersebut merupakan sebuah syarat yang harus dipenuhi untuk mencapai tata ruang kantor yang baik. (Gie, 2007:188). Tujuan yang harus dicapai tersebut adalah:

Proses pelaksanaan pekerjaan kantor dapat menempuh jarak yang sependek mungkin.

- Aktivitas tata usaha berjalan secara lancar

- Penggunaan tata ruang efisien untuk keperluan pekerjaan

- Tercapainya kepuasan bekerja para pegawai

- Pekerjaan pegawai dapat diawasi dengan mudah

${ }^{2}$ Ida Nuraida, Manajemen Administrasi Perkantoran (Depok: PT Kanisius, 2014), 1

${ }^{3}$ Ibid, 161-162 
- Menampilkan kesan yang baik bagi pihak luar yang mengunjungi kantor

- Susunan tempat kerja yang mudah untuk diubah sewaktuwaktu

Selain itu syarat yang harus dipenuhi untuk mencapai tata ruang kantor, (Haryadi, 2009:122). Tujuan yang harus dicapai tersebut adalah:

- Seluruh ruangan yang ada dapat dimanfaatkan untuk keuntungan ekonomis yang besar.

- Memudahkan pengawasan manajer kepada para pegawai yang sedang bekerja.

- Arus kerja yang baik mempengaruhi kualitas arus komunikasi.

- Penataan ruangan yang baik dapat memberikan kepuasan dan kenyamanan dalam bekerja, sehingga pegawai merasa nyaman bekerja di kantor.

- Tersedianya layanan yang dibutuhkan oleh pegawai dalam melaksanakan pekerjaannya.

- Memudahkan pegawai dalam menyimpan arsip, khususnya untuk arsip aktif.4

Apabila tujuan penatan ruang kantor tersebut telah terpenuhi maka akan menimbulkan manfaat bagi pegawai kantor. Salah satu manfaatnya adalah membuat pegawai menjadi nyaman dalam melakukan pekerjaanya sehingga dapat optimal dalam melakukan setiap aktivitas pekerjaannya. Badri Munir Sukoco (2007:189) berpendapat bahwa pentaan ruang kantor yang efektif akan menimbulkan bebrapa manfaat anatara lain:

- Memaksimalkan penggunaan ruang secara efektif.

- Mengambangkan lingkungan bekerja yang nyaman bagi pegawai

- Meningkatkan produktifitas kerja bagi pegawai

- Menjamin arus kerja yang ada serta efisiensi kerja

\footnotetext{
${ }^{4}$ Alfian Aulia Rochman,Tugas Akhir : 'Pengelolaan Tata Ruang Kantor Pada Sub Bagian Perencanaan Dan Keuangan Dinas Pekerjaan Umum Kabupaten Semarang” (Semarang: Universitas Negeri Semarang, 2015), 11
} 
- Memberikan kesan yang baik kepada masyarakat yang memasuki ruang kantor tersebut. 5

Terdapat beberapa asas yang harus dipenuhi dalam pengelolaan penataan ruang kantor yang baik. Sehingga dapat diperoleh tata ruang yang sempurna. Menurut Richard Muther terdapat enam asas, yakni:

Asas jarak terpendek

Ketika menyusun tempat kerja dan penempatan peralatan untuk bekerja hendaknya memperhatikan asas ini dengan baik. Proses penyelesaian suatu pekerjaan diusahakan agar menempuh jarak yang sependek-pendeknya. Yang dimaksud jarak sependekpendeknya adalah garis lurus antara dua titik.

Asas rangkaian kerja

Jarak terpendek akan tercapai apabila para pegawai atau alatalat ditempatkan berurutan sesuai urutan proses penyelesaian pekerjaan. Setiap langkah untuk menyelesaikan pekerjaan hendaknya menggunakan alur maju, tidak mundur ataupun menyilang.

\section{Asas mengenai penggunaan segenap ruang}

Seluruh ruang yang ada dipergunakan dengan sebaik-baiknya sehingga tidak ada ruang yang dibiarkan tidak terpakai. Ruang tersebut tidak hanya berupa luas lantai (ruang datar), melainkan juga ruangan yang vertical ke atas maupun ke bawah.

Asas mengenai perubahan susunan tempat kerja

Apabila dimungkinkan adanya perubahan atau penyusunan kembali ruang kantor jika diperlukan. Tanpa banyak kesulitan dan tidak memakan biaya yang besar.

Asas keamanan dan kepuasan kerja bagi pegawai

Tata ruang kantor harus membuat pegawai merasa nayaman, aman, dan puas dalam melakukan pekerjaannya. 6

\footnotetext{
${ }^{5}$ Firda Noor Oktavianti, “Analisis Tata Ruang Dalam Kenyamanan Kerja Dan Optimalisai Kinerja Bagian Humas Dan Protocol Secretariat DPRD Kota Surakarta”, Jurnal Informasi Dan Komunikasi, Volume 2 Nomor 3, 2018, 74

${ }^{6}$ Ida Nuraida, Manajemen Administrasi Perkantoran (Depok: PT Kanisius, 2014), 165
} 
Terdapat beberapa pendekatan praktis yang dapat digunakan dalam kegiatan perencanaan tata ruang kantor yang baik. Pendekatan ini di ungkapkan oleh Moekijat (2008:16). Pendapat tersebut yakni:

- Gunakan skala dalam membuat rencana ruangan kantor.

- Perhatikan rencana jalan masuk, jendela dan yang lainnya,

- Tentukan jumlah dan ukuran semua perlengkapan dan perkakas,

- Menggunakan model dari semua perkakas dan perlengkapan,

- Berduskusi dengan kepala-kepala seksi mengenai ruangan yang diperlukan pegawai,

- Membuat model rencana yang sesuai dengan prinsip ataupun asas dalam perencanaan dalam tata ruang kantor,

- Memperhatikan nama pekerja telepon dan sebagainya.

Pembagian macam tata ruang kantor pada umumnya terdapat dua macam yakni ruang kantor terbuka dan tertutup dengan penjelasan sebagai berikut:

\section{Ruang kantor terbuka}

Seluruh aktivitas dilaksanakan secara bersama-sama oleh pegawai dalam ruangan besar yang terbuka yang tidak dipisahkan oleh tembok atau penyekat. Keuntungan dari tata ruang ini adalah:

- Mempermudah dalam penataan ruang tanpa perlu biaya yang tinggi

- Mempermudah koordinasi dan komunikasi antar pegawai

- Menghemat penggunaan penerangan dan peralatan kerja

- Mempermudah dalam penempatan, penggunaan, dan perawatan peralatan kerja

- Mempermudah pengawasan kerja pegawai oleh pimpinan Sementara kerugian dari tata ruang ini adalah:

- Sulit untuk melakukan pekerjaan yang bersifat privasi

- Memerlukan AC untuk mengurangi debu dan mendinginkan udara

- Memungkinkan terjadinya keramaian yang menganggu konsentrasi kerja.

\section{Ruang Kantor Tertutup}


Tempat untuk bekerja berada di dalam kamar-kamar atau ruangan yang dipisahkan oleh tembok atau penyekat.

Keuntungan dari tata ruang ini adalah :

- Lebih cocok untuk pekerjaan yang bersifat privasi baik dari segi pembicaraan, dokumen, atau aset yang berharga.

- Lebih mudah konsentrasi terhadap pekerjaan

- Dapat menghargai tamu yang datang.

Sementara kerugian dari tata ruang ini adalah:

- Dibutuhkannya biaya yang tinggi untuk memisahkan ruanagan, lebih banyak menggunakan alat komunikasi, penerangan, ventilasi, peralatan kantor dan pemliharaannya.

- Sulit merubah tatanan kantor atau fleksibilitas ruangan.

- Koordinasi dan komunikasi lebih sulit

- Mempersulit dalam pengawasan kerja. 7

Dalam pengelolaan tatanan ruang kantor juga perlu untuk memperhatikan penyusun perabotan kantor. Perabot merupakan sebuah perlengkapan kantor yang memiliki tujuan untuk membantu proses tata usaha secara tidak langsung. Perabot kantor terdiri dari lemari, lemari arsip, lemari katalog, meja, kursi, rak, asbak, dan perlengkapan lainnya yang diberikan kepada pegawai secara perseorangan atau untuk umum.

- Terdapat beberapa teknik yang dapat digunakan untuk mencapai suatu tata ruang kantor yang baik. Teknik tersebut yakni:

- Meja kerja disusus dengan pola garis lurus dan menghadap kejurusan yang sama. Hal ini akan mengurangi kemungkinan para pegawai sering mengobrol atau memperhatikan apa yang dikerjakan oleh rekannya.

- Susunan meja dapat terdiri dari beberapa baris bagi tata ruangan yang terbuka. Dan diantara baris meja tersebut disediakan lorong untuk keperluan para pegawai. Selain itu perhatikan pula jarak antara satu meja dengan meja yang lainnya. Dan juga tempat duduk.

${ }^{7}$ Ida Nuraida, Manajemen Administrasi Perkantoran (Depok: PT Kanisius, 2014), 162 
- Pimpinan kantor ditempatkan di bagian belakang pegawai karena akan lebih mudah dalam mengawasi pegawainya.

- Apabila banyak pekerja yang dikelompokkan di bawah pengawasan seorang pejabat, maka mereka akan ditempatkan pada sekat masing-masing pejabat yang mengawasi dan bertanggung jawab terhadap kelompok tersebut. Teknik ini digunakan pada tata ruang yang terbuka

- Pemberian tempat yang banyak memperoleh cahaya bagi pegawai yang mengerjakan pekerjaan lembut, misalnya pekerjaan mencatat angka kecil secara cermat atau melukis gambar yang halus.

- Penempatan pegawai yang bertugas mengenai urusan yang mengandung resiko ditempatkan di bagian pojok yang tidak sering dilalui banyak orang.

- Lemari serta alat perlengkapan lainnya di taruh di dekat pegawai yang sering menggunakan benda tersebut.

- Pegawai yang sering berinteraksi dengan masyarakat di tempatkaan di dekat pintu. Dengan seperti itu maka orang asing yang harus menghubunginya tidak harus mondar-mandir melewati meja lainnya dan tidak mengganggu pegawai lainnya.

- Bagi pemimpin yang sering menerima tamu penting untuk membicarakan urusan yang sifatnya rahasia dapat dibuatkan ruang tamu sendiri. 8

Menurut The Liang Gie (2007: 195) terdapat empat hal yang dapat mempengaruhi efisiensi pekerjaan perkantoran, yakni:

\section{Cahaya}

Cahaya merupakan faktor yang penting untuk meningkatkan efisiensi kerja pegawai. Hal tersebut dikarenakan cahaya mempengaruhi kesehatan pegawai, keselamatan kerja, serta kelancara kerja pegawai. Penerangan yang baik merpakan hal yang

\footnotetext{
${ }^{8}$ Alfian Aulia Rochman,Tugas Akhir : 'Pengelolaan Tata Ruang Kantor Pada Sub Bagian Perencanaan Dan Keuangan Dinas Pekerjaan Umum Kabupaten Semarang” (Semarang: Universitas Negeri Semarang, 2015), 22
} 
utama dibutuhkan oleh indra penglihatan agar dapat melaksanakan tugas kantor secara maksimal. 9.

Pemilihan pencahayaan bagi kantor harus dilakukan dengan tepat agar tidak terjadi gangguan dalam proses kerja pegawai. Terdapat empat jenis cahaya yang biasanya digunakan dalam ruangan kantor:

- Cahaya alami, yakni cahaya yang berasal dari sinar matahari

- Cahaya fluorescent, yakni cahaya dengan tingkat terang yang mirip dengan cahaya alami. Kelebihan dari cahaya ini menghasilkan lebih sedikit panas dan silau, memiliki daya tahan yang lama, hemat listrik, serta lebih efisien.

- Cahaya incandescent, yakni cahaya yang banyak digunakan dirumah.

- High intensity discharge lamps, yakni cahaya yang biasanya dipakai di jalan raya ataupun stadion olahraga. Kelebihan dari cahaya ini adalah pencahayaan yang sangat efisien. Sedangka kelemahannya adalah menyulitkan untuk membedakan warna. 10

Sedangkan menurut The Liang Gie (2000:213-215) cahaya penerangan yang dibuat oleh amnesia dibagi menajdi empat bagian yakni cahaya langsung, cahaya setengah langsung, cahaya setengah tidak langsung, dan cahaya tidak langsung. 11

\section{Warna}

Warna meruipakan salah satu faktor yang penting untuk diperhatikan dalam pengelolaan tata ruang kantor. Terdapat beberapa faktor yang dapat dijadikan pertimbangan dalam pemilihan warna tembok kantor, faktor tersebut yaitu:

\footnotetext{
${ }^{9}$ Ida Nuraida, Manajemen Administrasi Perkantoran (Depok: PT Kanisius, 2014), 174.

${ }^{10}$ Rahmawati, Manajemen Perkantoran (Yogyakarta: graha ilmu 2014), 72.

${ }^{11}$ Firda Noor Oktavianti, “Analisis Tata Ruang Dalam Kenyamanan Kerja Dan Optimalisai Kinerja Bagian Humas Dan Protocol Secretariat DPRD Kota Surakarta”, Jurnal Informasi Dan Komunikasi, Volume 2 Nomor 3, 2018, 76.
} 
- Kombinasi warna, yakni kombinasi dari bebrapa warna primer seperti kuning, merah, dan biru. Dan dapat menghasilkan warna sekunder.

- Efek cahaya pada warna, berbagai macam cahaya buatan memiliki spectrum yang berbeda. System pencahayaan yang sering digunakan pada kantor juga memiliki efek yang signifikan terhadap pemilihan warna

- Nilai pemantulan warna.beberapa warna memiliki nilai pemantulan yang berbeda. Contohnya seperti warna yang lebih terang akan memantulkan presentase cahaya yang lebih besar daripada warna yang gelap.

- Dampak dari warna. Warna seringkali mempengeruhi mood. Biasanya warna yang sejuk menghasilkan mood yang tenang12

\section{Suara dan udara}

Tingkat kebisingan suara sangat mempengaruhi kinerja pegawai. Suasana kantor yang ramai dan berisik berpengaruh terhadap kinerja pegawai yang membutuhkan konsentrasi lebih. Mislnya bagian keuangan. Tingkat kebisingan pada kantor harus dipertimbangkan untuk mengelola tingkat produktivitas pegawai. Apabila tingkat kebisingan melampaui batas yang tiak diinginkan, beberapa gangguan fisik dan psikologis terhadap pegawai akan terjadi. Beberapa hal yang perlu untuk diperhatikan pada suara di perkantoran adalah bangunan yang sesuai, penggunaan material peredam suara, alat peredam suara, dan masking.

Lingkunagn kerja yang nyaman bukan hanya dipengaruhi oleh penerangan dan suara, melainkan adalah faktor udara atau sirkulasi udara dan keamanan. Ruangan yang terlalu dingin ataupun terlalu panas akan memepengaruhi kinerja pegawai. Oleh karena itu, kantor harus dapat mengontrol temperature udara dan tingkat kelembaban udara sesuai dengan kebiasaan pegawai.

Nyaman adalah suatu kondisi dimana seseorang merasa dihargai, merasa aman, bahagia, dan tidak ada beban fikiran. Kenyamanan dalam bekerja merupakan faktor penting dalam keberhasilan individu dan juga lembaga. Apabila seorang pegawai

${ }^{12}$ Rahmawati, Manajemen Perkantoran (Yogyakarta: graha ilmu 2014), 75. 
berhasil dalam pekerjaannya pasti memiliki rasa nyaman sehingga pegawai tersebut dapat melaksanakan pekerjaannya sesuai dengan yang diinginkannya, atau bahkan melebihi ekspektasinya dan juga lembaganya. Menurut KBBI nyaman adalah kondiis dimana seseorang merasa aman, enak, bersih, sejuk, damai, dan tenang. Kenyamanan didukung oleh beberapa faktor yakni keamanan dan kepercayaan. Para ahli mendefinisikan nyaman merupakan keadaan bebas dari gangguan, bebas dari keadaan was-was, bebas dari rasa iri dan dengki, bebas dari rasa rendah diri, bebas dari rasaa sombong, merasa cukup dengan apa yang dimilikinya, tidak merasa kurang dengan apa yang telah diterimanya. 13

Apabila pengelolaan penataan ruang kantor dilakukan dengan baik, dengan menerapkan asas-asas yang telah ada serta memperhatikan kondisi fisik seperti cahaya, warna, suara, dan udara maka akan terciptanya kenyamanan pegawai dalam bekerja. Apabila pegawai telah nyaman dalam melakukan pekerjaannya hal tersebut akan meningkatkan produktivitas kerjanya.

\section{Metodologi}

Penelitian ini menggunakan jenis penelitian kualitatif. Penelitian klualitatif merupakan penelitian yang menganut pada aliran fenomenologis, yang menitikberatkan kegiatan penelitian ilmiahnya dengan penguraian dan pemahaman terkait gejala-gejala social yang sedang diamati. Penelitian dilakukan pada tanggal 15-16 Oktober 2020 dan lokasi yang kami gunakan sebagai tempat penelitian adalah Seksi Bimbingan Masyarakat Islam pada Kantor Kementrian Agama Kota Mojokerto.

13 Website Resmi Pemerintah Kabupaten Buleleng, Pentingnya Kenyamanan Dalam Bekerja, Diakses Pada 16 Oktober 2020 Dari https://bulelengkab.go.id/detail/artikel/pentingnya-kenyamanan-dalambekerja-

84\#: :text=Nyaman\%20adalah\%20kondisi\%20dimana\%20kita,dan\%20tid ak\%20ada\%20beban\%20pikiran.\&text=Harus\%20diakui\%20bahwa\%20ke nyamanan\%20bekerja,keberhasilan\%20individu\%20dan\%20juga\%20organ isasi. 
Sumber data dalam penelitian kualitatif dapat berupa manusia, peristiwa, dan tingkah laku, dokumen dan arsip, serta beberapa benda lain. Sumber data dalam penelitian ini adalah informan, karena informan merupakan pelaksana dalam kegiatan yang hendak kami teliti. Informan dalam penelitian ini adalah pelaksana tugas kepala seksi bimbingan masyarakat islam dan pegawai yang bekerja pada seksi bimbingan masyarakat islam.

Instrument penelitian dalam penelitian kualitatif adalah peneliti itu sendiri. Oleh karena itu sebagai instrument, peneliti juga harus di validasi seberapa jauh peneliti kualitatif melakukan penelitian yang selanjutnya akan terjun ke lapangan. Jadi instrument kunci dalam penelitian kualitatif adalah peneliti itu sendiri. Teknik pengumpulan data merupakan langkah yang strategis dalam penelitian, karena memiliki tujuan untuk mendapatkan data. Tanpa kita mengetahui teknik pengumpulan data, peneliti tidak akan mendapatkan data sesuai dengan standar yang telah ditetapkan. Teknik pengumpulan data yang digunakan adalah teknik wawancara, dokumentasi, dan observasi.

Wawancara merupakan tanya jawab antara dua orang atau lebih secara langsung dengan maksud tertentu. Disini peneliti akan mewawancarai Plt. Kasi Bimbingan Masyarakat Islam dan pegawai yang bekerja di Seksi Bimbingan Masyarakat Islam. Melalui metode observasi atau pengamatan maka peneliti akan melihat secara langsung perilaku dan kejadian yang sebenarnya terjadi di lokasi tempat peneliti melakukan penelitian. Pengamatan atau observasi dilakukan untuk meperoleh informasi tentang lingkungan dan kondisi tata ruang kantor serta fasilitas yang ada di kantor seksi bimbingan masyarakat islam.

Teknik pengumpulan data dengan menggunakan metode dokumentasi merupakan pengambilan data yang diperoleh melalui dokumen-dokumen. Dokumentasi diperlukan untuk mengumpulkan data berupa struktur organisasi, foto-foto, serta dokumen lain yang berhubungan dengan pengelolaan penataan ruang kantor pegawai.

Analisis data merupakan sebuah proses untuk mencari dan menyusun secara sistematis data yang diperoleh dari hasil 
pengumpulan data, sehingga data tersebut dapat dengan mudah dipahami, serta semuannya dapat diinformasikan kepada orang lain. Berdasarkan data yang telah dikumpulkan oleh peneliti dari lapangan, maka langkah selanjutnya yang dilakukan oleh peneliti adalah

Adapun untuk Uji validitas data adalah dengan menggunakan triangulasi. Triangulasi merupakan teknik untuk memeriksa keabsahan data yang memanfaatkan sesuatu yang ada di luar data tersebut untuk keperluan pembanding terhadap data tersebut.

\section{Hasil dan Pembahasan}

Seksi Bimbingan Masyarakat Islam merupakan salah satu satuan kerja di Kantor Kementrian Agama Kota Mojokerto yang mengurusi Urusan Agama Islam seperti Pernikahan, kemasjidan, zakat waqaf, dan lain sebagainya. Seksi bimas memiliki satu ruang kantor yang terletak bersebelahan dengan ruang seksi penyelenggaraan haji dan umroh. Terdapat tiga pegawai yang bekerja di ruangan tersebut. Serta terdapat satu ruang kepala seksi. Tetapi ruang kepala seksi tersebut tidak pernah ditempati karena kepala seksi bimas telah meninggal dunia. Ruangan tersebut digunakan untuk menyimpan arsip surat nikah dan arsip penting lainnya. Kepemimpinan kepala seksi bimas digantikan oleh Pelaksana tugas Kasi Bimas Islam yakni bapak Bambang Sunaryadi.

Pengelolaan penataan ruangan kantor pada seksi bimas telah menerapkan beberapa tujuan dari penyusunan tata ruang kantor seperti proses pelaksanaan pekerjaan kantor yang telah memenuhi jarak yang pendek, tersedianya layanan yang dibutuhkan pegawai dalam bekerja. Tetapi ada juga yang masih belum terpenuhi seperti pelaksanaan pekerjaan kantor yang dapat menempuh jarak sependek-pendeknya belum terpenuhi karena ruangan pimpinan yang tidak menjadi satu degan pegawai. Hal ini dikarenakan kepala seksi bimas islam telah meninggal dan tugasnya digantikan oleh pelaksana tugas kepala seksi bimas islam yang posisinya juga menjadi kepala seksi penyelenggaraan haji dan umroh. Dan juga susunan tempat kerja pegawai yang susah untuk diubah sewaktuwaktu karena kondisi ruangan yang cukup sempit. 
Pengelolaan penataan ruangan kantor pada seksi bimas telah menerapkan beberapa asas-asas tata ruang kantor tetapi masih ada yang belum diterapkan dengan sempurna. Berikut ini adalah penjelasan mengenai penerapan asas-asas tata ruang kantor pada seksi bimas islam:

\section{Asas jarak terpendek}

Asas jarak terpendek merupakan suatu hal yang menyangkut proses penyelesaian pekerjaan karyawan dengan jarak tempuh yang pendek. Asas ini belum sepenuhnya terpenuhi, karena letak pegawai bagian pengarsipan berada di sebelah selatan, sedangkan lemari arsip berada di sebeleh utara. Hal ini membuat pegawai yang telah melakukan pencatatan arsip apabila ingin menyimpan arsip ke lemari arsip harus bolak balik antara meja kerjanya dengan lemari arsip.

Selain itu ruang kepala seksi yang tidak menjadi satu degan pegawai. Hal ini karena kepala seksi bimbingan masyarakat islam teleh meninggal, sedangkan sekarang jabatan tersebut digantikan oleh pelaksanan tugas kepala seksi bimas islam yang juga menjabat sebagai kepala seksi penyelenggaraan haji dan umroh. Hal demikian membuat pegawai yang memiliki keperluan dengan kepala seksi harus pergi ke luar ruangan seksi bimas dan menemui yang bersangkutan di ruang kasi haji.

\section{Asas rangkaian kerja}

Alat kantor atau perlengkapan harus ditempatkan sesuai dengan kebutuhan para pegawai yang menggunakannya. Alat kantor yang berada di meja pegawai sudah tertata sesuai dengan kebutuhan masing-masing pegawai. Penataan meja kerja pegawai disusun membentuk huruf L. apabila peletakan alat kantor diletakkan terpencar maka akan membuthkan waktu lagi untuk mencarinya. Mengani alat kantor seperti alat tulis sudah ada di meja kerja pegawai masing-masing. Setiap meja kerja pun sudah dilengkapi dengan computer.

\section{Asas mengenai penggunaan segenap ruang}

Ruang seksi bimbingan masyarakat islam memiliki berbagai perabotan kantor yang cukup banyak, sehingga dalam penempatannya menggunakan seluruh celah ruang yang ada. 
Seperti lemari arsip, filling cabinet, dan rak arsip. Arsip yang tidak muat disimpan di lemari arsip dan rak arsip disimpan di dalam kardus lalu ditaruh di sebelah rak arsip. Seluruh perabotan yang ada sudah memenuhi hamper seluruh bagian ruangan di seksi bimas islam.

\section{Asas mengeneai perubahan susunan kerja}

Asas pemindahan susunan tempat kerja di seksi bimas islam ini belum diterapkan. Sejak dulu susunan kerja pegawai seksi bimas tetap sama seperti sekarang. Hanya saja terjadi pergantian pegawai. Salah satu pegawai yang dahulunya bekerja di seksi ini sekarang dipindah ke MAN Kota mojokerto.

\section{Asas keamanan dan kepuasan kerja bagi pegawai}

Tata ruang kantor diharapkan dapat memberikan kenyamanan pada pegawai dalam melaksanakan pekerjaannya. Tetapi hal tersebut masih belum diterapkan sepenuhnya. Berdasarkan hasil wawancara kami dengan pegawai seksi bimbingan masyarakat islam, sebagian dari mereka menyatakan nyaman dalam bekerja tetapi ada beberapa hal yang memebuat mereka menjadi tidak nyaman. Hal tersebut yakni :

- Tidak adanya sekat antara pegawai satu dengan yang lainnya. Akibatnya kurang terjaganya privasi setiap pegawai.

- Tidak adanya pengaman pada meja pegawai. Hal ini memungkinkan orang lain untuk mengambil dokumen atau barang dari meja pegawai tersebut.

- Kurangnya fasilitas untuk penyimpanan arsip. Hal tersebut dikarenakan ruangan bimas yang tidak cukup besar dan dokumen penting yang disimpan pun banyak.

Kantor seksi bimbingan masyarakat islam memiliki jenis kantor terbuka. Yang mana seluruh aktivitas dilaksanakan secara bersamasama oleh pegawai dalam ruangan besar yang terbuka dan tidak dipisahkan oleh tembok atau perekat. Jenis ruangan ini memang banyak menguntungkan, apalagi ruangan bimas yang tudak cukup besar karena ruangan akan tampak lebih luas. Hal tersebut terjadi karena tidak adanya penyekat antar pegawai. Dan kepala seksi akan mudah untuk memantau pegawainya. Tetapi dari jenis ruangan yang seperti itu juga memiliki kelemahan yakni kurang terjaganya 
provasi antar pegawai, serta memungkinkan terjadinya keramaian yang dapat mengganggu konsentrasi pegawai.

Penataan ruangan kantor bimas islam sudah menerapkan bebrapa teknik seperti meja telah disusun dengan pola garis lurus dan menghadap ke arah yang sama, dan penempatan pegawai yang bertugas mengenai urusan yang mengandung resiko ditempatkan di bagian pojok yang tidak sering dilalui banyak orang. Tetapi ada juga beberapa teknik yang belum diterapkan yakni ruang pimpinan yang berada di luar seksi bimas islam. Hal ini terjadi karena Plt kasi bimas juga menjabat sebagai kepala seksi penyelenggaraan haji dan umroh.

Kenyamanan bekerja pegawai juga dipengaruhi oleh cahaya, warna, udara, serta udara. Keempat hal tersbut nantinya juga akan mempengaruhi efisiensi pekerjaan perkantoran. Kantor bimas menggunakan cahaya tidak langsung, yakni cahaya yang hanya berasal dari lampu. Penerangan di kantor bimas islam menurut para pegawai yang bekerja disana sudah cukup terang dan membuat nyaman, hanya saja lampu yang seharusnya ada dua, hanya menyala satu.

Warna dinding di bagian bimas islam selaras dengan warna symbol kementrian agama yakni warna hijau. Warna dinding ruangan bimas islam yakni hijau muda, pemilihan warna dirasa tepat. Karena dengan warna tersebut sudah sesuai dengan pencahayaan yang digunakan, sehingga menimbulkan kenyamanan bagi pegawai bimas dalam bekerja.

Suara pada ruang bimas islam tidak bising. Akan tetapi karena ruangan bimas tidak memiliki sekat pemisah antar pegawai satu dengan yang lainnya membuat keramaian antar pegawai ketika berbicara. Apabila terjadi keramaian antar pegawai ketika sedang berbicara akan menimbulkan rasa tidak nyaman dalam bekerja.

Sirkulasi udara pada ruanagan seksi bimas islam sudah cukup bagus. Ruang bimas islam memiliki satu AC, yang memiliki suhu standar. Tidak terlalu dingin dan juga tidak terlalu panas. Menurut para pegawai yang bekerja pada seksi bimas, hal tersebut sudah cukup membuat nyaman dalam bekerja. 
Salah satu hal yang dapat membuat kenyamanan dalam bekerja adalah pengelolaan penataan ruang kantor yang baik. Apabila pengelolaan penataan ruang kantor sudah dilakukan dengan baik dan memenuhi asas-asas penataan ruang kantor maka akan membuat pegawai menjadi nyaman dalam bekerja. Apabila pegawai telah merasa nyaman dalam melakukan pekerjaannya, maka akan mempercepat dalam penyelesaian pekerjaan, sehingga meningkatkan kinerja dari pegawai tersebut.

\section{Kesimpulan}

Berdasarkan pemaparan materi serta hasil penelitian yang telah peneliti lakukan pada seksi bimbingan masyarakat islam kantor kementrian agama kota mojokerto, pengelolaaan penataan ruang kantor seksi bimas islam belum sepenuhnya efektif dan efisien untuk melakukan berbagai macam pekerjaan. Terdapat berbagi kendala yang harus diatasi yaitu dengan penataan kembali ruang kantor bimas.

Kurangnya kenyamanan bagi para pegawai dalam melakukan pekerjaannya. Hal ini karena jenis ruangan kantor bimas islam merupakan ruangan terbuka, sehingga kurang terjaganya privasi dalam bekerja. Kurangnya space untuk meyimpan arsip dam juga penataan arsip yang kurang rapi. Penataan arsip yang kurang rapi menimbulkan ketidaknyamanan dalam bekerja.

Pengelolaan penataan ruang kantor merupakan salah satu hal yang dapat membuat kenyamanan dalam bekerja. Apabila pengelolaan penataan ruang kantor sudah dilakukan dengan baik dan memenuhi asas-asas penataan ruang kantor maka akan membuat pegawai menjadi nyaman dalam bekerja. Kinerja pegawai akan meningkat apabila pegawai telah merasa nyaman dengan penataan ruang kantor yang ada, seperti yang sudah dipaparkan dalam materi di atas.

Berdasarkan hasil penelitian yang telah peneliti lakukan, disini peneliti akan memberikan sedikit saran yang bisa dipertimbangkan untuk pengelolaan penataan ruang kantor pada ruang kantor seksi bimas islam agar menciptakan kenyamanan pegwai dalam bekerja yakni: 
Sebaiknya penyusunan tempat kerja pegawai membentuk huruf U. karena apabila tidak ada penyekat, dengan bentuk huruf $U$ akan sedikit menjaga privasi pegawai dalam bekerja. Selain itu disarankan agar memperbaiki penataan arsip sehingga terlihat lebih rapi

\section{References}

Hardani. 2020. Metode Penelitian Kualitatif dan Kuantitatif. Yogyakarta: Pustaka Ilmu

Nuraida, Ida. 2014. Manajemen Administrasi Perkantoran. Depok: PT Kanisius

Oktavianti, Firda Noor. 2018. Analisis Tat Ruang Dalam Kenyamanan Kerja Dan Optimalisai Kinerja Bagian Humas Dan Protocol Secretariat DPRD Kota Surakarta. Jurnal Informasi Dan Komunikasi, Volume 2 Nomor 3.

Rahmawati. 2014. Manajemen Perkantoran, Yogyakarta: Graha Ilmu 2014)

Rochman, Alfian Aulia. 2015. Tugas Akhir : Pengelolaan Tata Ruang Kantor Pada Sub Bagian Perencanaan Dan Keuangan Dinas Pekerjaan Umum Kabupaten Semarang. Semarang: Universitas Negeri Semarang

Website Resmi Pemerintah Kabupaten Buleleng, Pentingnya Kenyamanan Dalam Bekerja, Diakses Pada 16 Oktober 2020 Dari https://bulelengkab.go.id/detail/artikel/pentingnyakenyamanan-dalam-bekerja-

84\#: :text=Nyaman\%20adalah\%20kondisi\%20dimana\%20kita, dan\%20tidak\%20ada\%20beban\%20pikiran.\&text=Harus\%20d iakui\%20bahwa\%20kenyamanan\%20bekerja,keberhasilan\%20 individu\%20dan\%20juga\%20organisasi 